\title{
Effect of calf suckling on oxytocin, prolactin, growth hormone and milk yield in crossbred Gir $\times$ Holstein cows during milking
}

\author{
João Alberto NEGRÃO ${ }^{a *}$, Pierre-Guy MARNET ${ }^{b}$ \\ a USP/FZEA, FAPESP, Cx. Postal 23, 13630-970, Pirassununga/SP, Brazil \\ b UMR Production du lait, INRA/ENSAR, Rennes, France
}

(Received 18 April 2002; accepted 20 July 2002)

\begin{abstract}
This study evaluated the effect of different milking managements on oxytocin, prolactin and growth hormone release in Gir $\times$ Holstein cows. Six cows were suckled by their calves, before and after milking (SM group); another six cows were submitted to exclusive milking (M group). High OT levels were observed during suckling of the SM group, however both groups had similar levels of OT during milking. The SM group presented PRL levels significantly higher than the M group, however only during suckling. For GH levels, the SM group showed higher levels than the $\mathrm{M}$ group, however this difference was significant only during the first suckling, cleaning of the teats and at the beginning of machine milking. Despite these results, SM cows produced more milk (milking plus suckling) than M cows, however milk obtained by milking was similar for both groups.
\end{abstract}

cows / crossbred / milking / suckling / hormone

\section{INTRODUCTION}

Unspecialized cattle farmers in Brazil have used crossbred Gir (Bos indicus) $\times$ Holstein (Bos taurus) cows to produce both milk and calves during the spring and summer in extensive systems [1] because these crossbred animals are well adapted to tropical conditions $[39,40]$. In many cases, this system is economically viable and farmers maintain Gir $\times$ Holstein cows [19].

However, some studies with Bos indicus $\times$ Bos taurus cows have demonstrated that these animals are susceptible to lactation failure $[1,26]$ and retain high levels of residual milk after machine milking [26]. In Brazil, Gir cows have been continuously

* Correspondence and reprints

E-mail: jnegrao@usp.br 
selected for milk yield $[22,38]$ and at present Gir $\times$ Holstein cows exhibit a normal lactation [20]. For these reasons, this crossbreeding program is considered a success $[19,21]$ and some farmers are now specializing in producing crossbred cows for replacements on other dairy farms [21].

In general, Gir $\times$ Holstein cows are reputed not to be well-adapted to machine milking, and many crossbred cows are milked in the presence of their calves, like other breeds considered not well-adapted to exclusive machine milking [4, 31]. Thus crossbred cows are often suckled by their calves immediately before and after milking $[34,35]$. Other works have observed that Holstein cows [5] and Lacaune ewes [23] submitted to a combined milking and suckling system produced more milk than during exclusive milking. This management of combined milking and suckling increases the labour of milkers and has been shown to inhibit OT release and decrease milk production in some cases following weaning $[23,41]$.

Some previous works have studied the influence of a combined milking and suckling system on milk production in crossbred cows $[4,34,35]$. However, these experiments did not analyse hormone release around milking and milking adaptation of crossbred Bos indicus $\times$ Bos taurus cows to exclusive machine milking has not been described in the literature. Thus, the objective of the present study was to evaluate the effect of different milking managements on oxytocin (OT), prolactin (PRL) and growth hormone $(\mathrm{GH})$ release and on milk yield in crossbred Gir $\times$ Holstein cows.

\section{MATERIALS AND METHODS}

The experiment was carried out at the beginning of the summer (the humid season), using 12 crossbred cows (Gir, Bos taurus $\times$ Holstein, Bos indicus) with a proportion of 3/4 Holstein blood (F2). All experimental cows had free access to water, pasture (Panicum maximum) and a vitamin/mineral mixture. Before each milking, each cow received a mixture of grain in an individual tie-stall, according to their production. Periodic control of the total diet was effected and when necessary, additional concentrate was furnished to provide adequate nutrients for milk production [27].

Experimental cows were divided into two homogeneous groups, with similar lactation number, lactation stage and level of milk production. To avoid the influence of previous milking management in the present experiment, we used cows that had been submitted to the same milking management as in their previous lactation (exclusive milking or suckling and milking combination). All 12 experimental cows were milked twice/day (at 6 and $18 \mathrm{~h}$ ). Six cows were suckled by their calves, immediately before and after milking thus forming the SM Group; the 6 other cows were separated from their calves and submitted to exclusive milking thus forming the $\mathrm{M}$ group.

\subsection{Suckling and milking}

Suckling lasted 2 min before milking (from -4 to $-2 \mathrm{~min}$ ) and 2 min after milking (from 12 to $40 \mathrm{~min}$ ). Each calf suckled its own mother, and during milking calves remained tied beside their mother and tactile, visual and vocal contact were possible. Milk consumed by the calves during suckling was measured by weighing the calves before the first suckling and after the last experimental suckling.

Milking machine parameters were constant throughout the experiment. The settings for the low line milking machine (Westfalia Elk Grove Village, IL) were a vacuum of $45 \mathrm{kPa}$, a pulsation ratio of $70: 30 \%$ and a pulsation rate of 60 cycles. $\mathrm{min}^{-1}$. Milking routines were constant and the same person performed all experimental milkings. Prestimulation was carried out before milking, during cleaning of the teats and the mastitis 
test for both groups (from -1 to $0 \mathrm{~min}$ ). However, hand milking was not applied. The teatcups were attached at time 0 and detached after interruption of the milk flow (machine milking lasted on average for $8 \pm 1.2 \mathrm{~min}$ ). Milk yield was recorded at each milking throughout lactation.

\subsection{Blood samples}

Blood samples were taken at the morning milkings on days 40, 41, 42 and 43 of lactation, before and after udder stimulation. At each experimental milking, samples were taken at: $-5,-3,-1,1,2,3,5,7,10,13$ and $15 \mathrm{~min}$. For both groups, the samples at -5 min were defined as basal levels, and the sample at 0.5 min was taken during the cleaning of the teats and the mastitis test. For the SM group, samples at -3 and at 13 min were taken at the middle of suckling, and each suckling duration was fixed at $2 \mathrm{~min}$ (calves suckled from $-4 \mathrm{~min}$ to $-2 \mathrm{~min}$ and from 12 to 14 min respectively).

Samples were collected in chilled heparinized tubes and immediately centrifuged at $4{ }^{\circ} \mathrm{C}$ and $3000 \mathrm{~g}$ for $15 \mathrm{~min}$. Plasma was preserved at $-20{ }^{\circ} \mathrm{C}$ until analysis. Plasma concentrations of OT were measured by the EIA method [24] and plasma concentrations of PRL and GH were determined using the RIA method [15].

\subsection{Statistical analysis}

SAS software [36] was used for evaluating data by means of analysis of variance, Student t-tests and Newman-Keuls tests. The probability level was $P<0.05$, and all values presented in this work are given as the mean \pm standard error of the mean (sem). The model used to evaluate the effect of type of milking management took the group, cow identity, time of sample, day of milking and all possible interactions into account. The relationships between milk yield and hormone levels were evaluated by Pearson correlations.

\section{RESULTS}

The hormone profiles are shown in Figure 1. OT levels measured during the cleaning of the teats were higher than the basal levels for both groups of cows. Highest OT levels were observed during suckling, however there was no significant difference between peaks measured during suckling and milking in the SM group. At the same time, both groups had similar levels of OT during machine milking. However, the hormone profiles observed during milking were different because OT increased more rapidly in the SM group (2 min after the beginning of milking) than in the M group (5 min).

Baseline levels of PRL were similar for both groups. In general, the SM group presented higher PRL levels than the M group but only during suckling were PRL levels significantly higher. However, PRL levels varied between sucklings and the PRL level observed during the suckling following milking was higher than that measured during the suckling before milking. It is important to observe that at the end of milking, PRL release increased for both groups (Fig. 1).

Although GH levels were significantly higher for the SM group than for the $M$ group, there were significant differences between groups only during the first suckling, cleaning of the teats and at the beginning of machine milking. As shown in Figure 1 , both groups presented similar levels of $\mathrm{GH}$ from $7 \mathrm{~min}$ to $15 \mathrm{~min}$, because the $\mathrm{M}$ group showed an increase in $\mathrm{GH}$ levels after the end of milking, while the GH levels of the SM group remained stable.

In contrast to the hormone results, milk production recorded during milking was similar for both groups $(\mathrm{SM}=14.68 \pm$ $0.26 \mathrm{~L}$ day $^{-1}$ and $\mathrm{M}=15.10 \pm 0.40 \mathrm{~L} \cdot \mathrm{day}^{-1}$ ). However, calves suckled $3.75 \pm 0.45 \mathrm{~L}$ day $^{-1}$, consequently SM cows produced more milk (milking plus suckling $=18.43 \pm$ $\left.1.22 \mathrm{~L} \cdot \mathrm{day}^{-1}\right)$ than the M cows (15.10 \pm $\left.0.40 \mathrm{~L} \cdot \mathrm{day}^{-1}\right)$. There were no significant correlations between the levels of hormones studied and milk yield. 

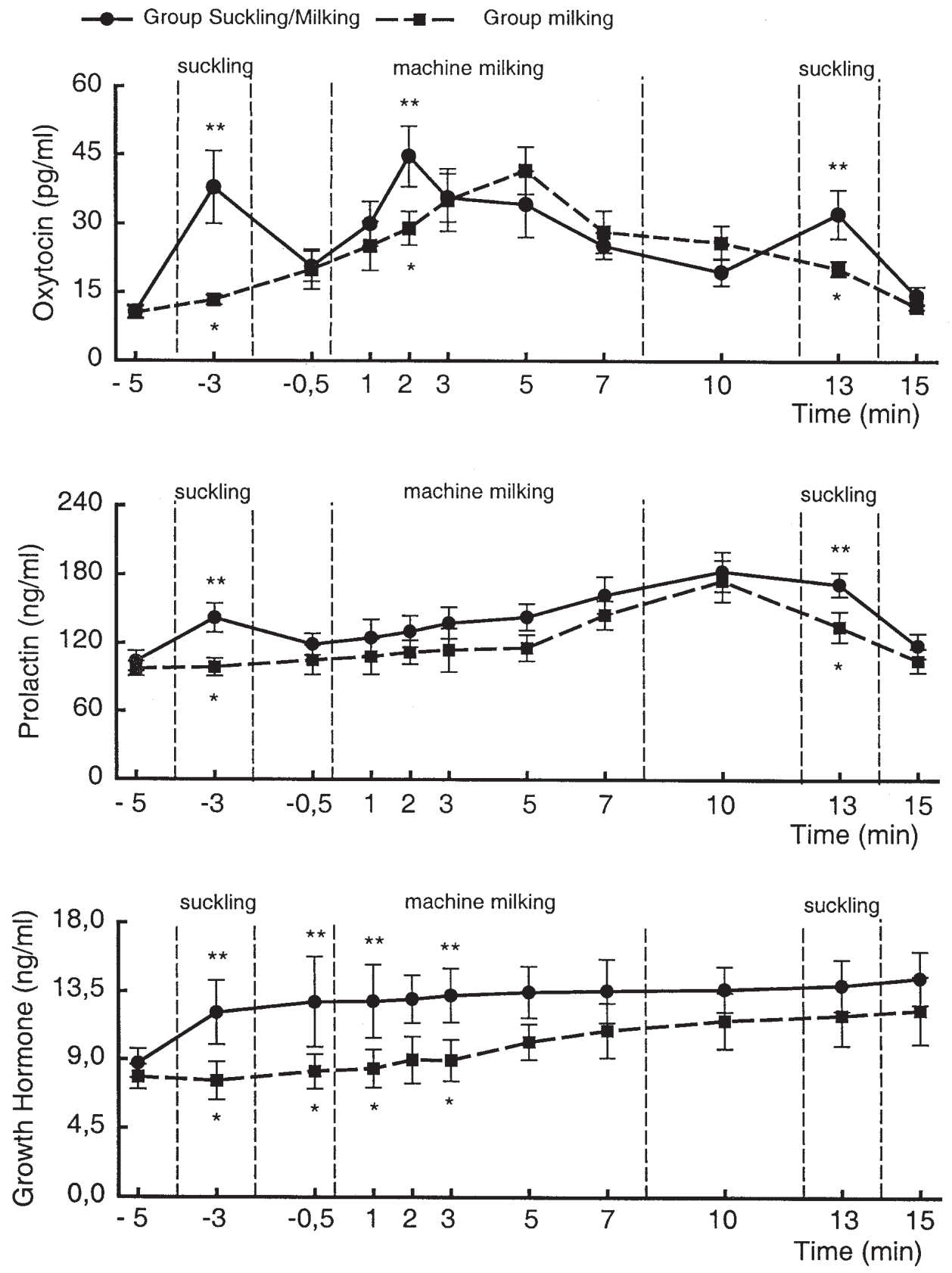

Figure 1. Oxytocin $(\mathrm{OT})$, prolactin $(\mathrm{PRL})$ and growth hormone $(\mathrm{GH})$ release (means \pm sem) before and after different milking managements with or without suckling in Gir $\times$ Holstein cows. Prestimulation was carried-out before milking (from -1 to $0 \mathrm{~min}$ ). The vertical dotted lines indicate the beginning and the end of suckling (from -4 to $-2 \mathrm{~min}$ and from 12 to $14 \mathrm{~min}$, respectively) or machine milking episodes (from 0 to $8 \mathrm{~min}$ ). Means with different symbols differ $P<0.05$. 


\section{DISCUSSION}

In this study, the baseline levels of OT, PRL and GH were similar for both groups of cows. Also, only OT levels had a slight but significant increase during the cleaning of the teats for all cows. As described in previous studies, pre-stimulation caused OT release $[9,13,25]$. Although OT levels first peaked during suckling in the SM group, OT peaks measured during suckling did not differ from the OT peaks measured during milking. In contrast, Holstein cows [5] and Lacaune ewes [23] showed the highest OT levels during suckling, however in these experiments suckling and milking were carried out at two distinct times.

In the present experiment, calves suckled immediately before milking. This prior udder stimulation probably influenced OT release and milk ejection during milking of the SM group. Consequently, OT increased more rapidly in the SM group (2 min after the beginning of milking) than in the $\mathrm{M}$ group (5 min). Nevertheless, OT levels measured at the first min of milking in the $M$ group were significantly higher than the basal levels. As demonstrated by other authors, small increases in OT levels reaching a threshold level are effective in inducing milk ejection in cows [37]. Furthermore, the variations in OT levels reported in the present experiment could be considered normal after a comparison of our results with those of other studies on Holstein cows submitted to exclusive machine milking $[9,14]$.

Apparently, in the present study the calf presence facilitated OT release during machine milking of the SM group, because the SM and M groups presented similar OT release during milking. In contrast, other authors have reported that dairy cows show higher OT release during suckling than milking in the calf's presence $[18,42]$. However, the difference between these results and our study could be attributed to the fact that the latter authors compared two different groups submitted to suckling or milk- ing in the calf's presence. It is possible that a combined milking and suckling system (consequently, milking in the calf's presence) has a positive effect on OT release and milk ejection for the Gir $\times$ Holstein cows of the SM group.

As shown by our results, the SM group presented higher PRL levels than the M group and PRL levels of the SM group were significantly higher during suckling than milking. Previously, other authors had demonstrated that the PRL release by cows during exclusive suckling was higher than during exclusive milking $[2,32]$, and that the calf's presence positively influenced PRL levels during milking [3]. Although PRL levels appeared to be superior during suckling than milking in a combined system of suckling and milking, these differences were not significant $[5,23]$.

It is important to observe that at the end of milking, the PRL release increased for both groups of cows. This explains why in the present work the difference between the groups was smaller during the suckling following milking, and indicates that suckling and milking stimulation improved PRL release. In the same way, other studies have demonstrated that machine milking continues influencing PRL levels several minutes after the end of milking [14, 28, 29]. Yet PRL is apparently not essential for galactopoiese in ruminants [33]. Recently, PRL administration in dairy goats has been found to significantly influence milk yield [16]. In dairy ewes, PRL is released during and after milking and milk yield decreases simultaneously from mid- to late-lactation [29].

Comparing GH levels measured in the present study, we observed that there was a significant difference between the groups of cows. This difference existed only at the beginning of udder stimulation (suckling, cleaning and the beginning of milking), because while GH levels remained stable for the SM group, GH levels increased after the end of milking for the M group. Other research has demonstrated that $\mathrm{GH}$ release is 
higher in a combined system of suckling and milking than in exclusive milking [5]. It is generally accepted that GH positively influences galactopoiese and since many studies have reported that exogenous $\mathrm{GH}$ increases milk yield [7, 10], it is interesting to know that it is possible to influence $\mathrm{GH}$ levels by udder stimulation.

Apparently, the stimulus induced by machine milking was effective in the present experiment because OT, PRL and GH were released during and after milking. In fact, milk obtained during milking was similar for the SM and M groups. Our experimental crossbred cows of both groups produced more milk than Gir cows [34, 35] and other crossbred Gir $\times$ Holstein cows [34, 35 ] but less milk than Holstein cows [5]. At the same time, our experimental calves suckled more than in previous studies with crossbred calves [34, 35]. Consequently, SM cows produced more milk (milking with more suckling) than $\mathrm{M}$ cows.

For the SM group, it is possible that milk obtained by machine milking was influenced by suckling at the previous milking. Other authors have already demonstrated that different management of cows and calves during milking could influence milk yield [5, $34,35]$ and calf growth $[11,35]$. It is important to note that the time of suckling was limited to $4 \mathrm{~min} / \mathrm{milking}$ during our experiment, and that normally the calf remains with crossbred cows for several hours after milking [35]. Thus it is possible that crossbred calves (that received a mixture of grain and had access to pasture), normally suck more milk than necessary for their development which would influence the amount of milk obtained during the next milking.

Although Bos taurus cows are welladapted to machine milking, cows managed in a combined system of milking and suckling may not eject milk during subsequent exclusive machine milking $[5,8]$. Indeed, milk yield shows a significant decrease when suckling is abruptly ceased in cows [5] and ewes [23]. As previously described, this kind of disturbance could be attributed to inhibition of OT release [23, 41], likely due to psychological stress caused by weaning [23]. However, OT release increases gradually several days after weaning and ewes then present a normal milk ejection [23].

Similarly, other authors have observed that crossbred cows susceptible to lactation failure exhibit high residual milk, and have suggested that inhibition of OT release is a possible explanation for lactation failure [26]. This could explain why cows with poor milk yield depend on frequent udder stimulation, and in many cases present a failure of lactation when submitted to the classical management strategy of 2 exclusive milkings/day. Furthermore, suckling after a period without suckling or milking has been shown to reinitiate milk secretion in beef cows [17].

In conclusion, it is possible that the beneficial effects of frequent milk removal could be partially attributed to the simultaneous release of OT, PRL and GH caused by udder stimulation. Several authors have demonstrated that $\mathrm{GH}$ administration [6], OT administration [30] or a combination of GH and PRL administration [12] has a positive effect on milk yield. It then seems possible that hormones released during and after udder stimulation have a concomitant action in milk synthesis, which remains to be elucidated. In this work, both types of milking management were effective in inducing OT, PRL and GH release in Gir $\times$ Holstein cows, however crossbred cows submitted to suckling before and after milking were more productive than those submitted to exclusive milking.

\section{ACKNOWLEDGMENTS}

We are grateful to Dr. Guy Kann for his advice and help with PRL and GH analyses. The present experiment was funded by FAPESP. 


\section{REFERENCES}

[1] Abubakar B.Y., Buvanendran V., Lactation curves of Friesian-Bunaji crosses in Nigeria, Livest. Prod. Sci. 8 (1981) 11-19.

[2] Akers R.M., Lefcourt A.M., Milking- and suckling-induced secretion of oxytocin and prolactin in parturient dairy cows, Horm. Behav. 16 (1982) 87-93.

[3] Akers R.M., Lefcourt A.M., Effect of presence of calf on milking-induced release of prolactin and oxytocin during early lactation of dairy cows, J. Dairy Sci. 67 (1984) 115-122.

[4] Alvarez F.J., Saucedo G., Arriaga A., Preston T.R., Effect on milk production and calf performance of milking crossbred European/Zebu cattle in the presence or absence of the calf and of rearing their calves artificially, Trop. Anim. Prod. 5 (1980) 25-37.

[5] Bar-Peled U., Maltz E., Bruckmental I., Folman Y., Kali Y., Gacitua H., Lehrer A.R, Relationship between frequent milking or suckling in early lactation and milk production of high producing dairy cows, J. Dairy Sci. 78 (1995) 2726-2736.

[6] Bauman D.E., Bovine somatotropin: review of an emerging animal technology, J. Dairy Sci. 75 (1992) 3432-3451.

[7] Bauman D.E., Vernon R.G., Effects of exogenous bovine somatotropine on lactation, Annu. Rev. Nutr. 13 (1993) 437-461

[8] Boden R.F., Leaver J.D., A dual purpose cattle system combination milk and beef production, Anim. Prod. 58 (1994) 463-464.

[9] Bruckmaier R.M., Blum J.W., Simultaneous recording of oxytocin release, milk ejection and milk flow during milking of dairy cows with and without prestimulation, J. Dairy Res. 63 (1996) 201-208.

[10] Chilliard Y., Roles and mechanisms of action of somatotropin (growth hormone) in lactating ruminants, Reprod. Nutr. Dev. 28 (1988) 39-59.

[11] Day M.L., Imikawa K., Clutter A.C., Wolfe P.L., Zalesky D.D., Nielsen M.K., Kinder J.E., Suckling behaviour of calves with dams varying in milk production, J. Anim. Sci. 65 (1987) 1207-1212.

[12] Flint D.J., Knight C.H., Interactions of prolactin and growth hormone in the regulation of mammary gland function and epithelial cell survival, J. Mammary Gland Biol. Neoplasia 2 (1997) 41-48.

[13] Gorewit R.C., Gassman K.B., Effects of duration of udder stimulation on milking dynamics and oxytocin release, J. Dairy Sci. 68 (1985) 1813-1818.

[14] Gorewit R.C., Svennersten K., Butler W.R. Uvnas-Moberg K., Endocrine responses in cows milked by hand and machine, J. Dairy Sci. 75 (1992) 443-448.
[15] Kann G., Dosage radioimmunologique de la prolactine plasmatique chez les ovins, C.R. Acad. Sci. 272 (1971) 2808-2811.

[16] Knight C.H., Overview of prolactin's role in farm animal lactation, Livest. Prod. Sci. 70 (2001) 87-96.

[17] Lamb G.C., Miller B.L., Lynch J.M., Grieger D.M., Stevenson J.S., Lucy M.C., Suckling reinitiated milk secretion in beef cows after an early postpartum hiatus of milking or suckling, J. Dairy Sci. 82 (1999) 1489-1496.

[18] Lupoli B., Johansson B., Uvnäs-Morberg K. Svennersten-Sjaunja K., Effect of suckling on the release of oxytocin, prolactin, cortisol, gastrin, cholecystokinin, somatostatin and insulin in dairy cows and their calves, J. Dairy Res. 68 (2001) 175-187.

[19] Madalena F.E., Aspectos económicos del mejoramiento genético del ganado lechero tropical, Rev. Argent. Prod. Anim. 15 (1995) 167-175.

[20] Madalena F.E., Trivedi K.R. Experience with performance recording of dairy cattle in Brazil, ICAR Technical Series 1 (1998) 235-246.

[21] Madalena F.E., Abreu C.P., Sampaio I.B.M., Sobrinho F.F., De Abreu C.A., MachadoSampaio I.B., Ferreira-Sobrinho F. Crossbreeding practice on dairy farms affiliated to the Central Farmers Cooperative in Minas Gerais State, Rev. Soc. Bras. Zoot. 26 (1997) 924-934.

[22] Magnabosco C. de U., Lobo R.B., Bezerra L.A.F., Martinez M.L., Estimate of genetic change in milk yield in a Gyr herd in Brazil Rev. Bras. Genet. 16 (1993) 957-965.

[23] Marnet P.G., Negrão J.A., The effect of a mixedmanagement system on the release of oxytocin prolactin and cortisol in ewes during suckling and machine milking, Reprod. Nutr. Dev. 40 (2000) 271-281.

[24] Marnet P.G., Volland H., Pradelles P., Grassi J., Beaufils M., Subpicogram determination of oxytocin by an enzyme immunoassay using acetylcholinesterase as label, J. Immun. 15 (1994) 35-53.

[25] Momogan V.G., Schmidt G.H., Oxytocin levels in the plasma of Holstein-Friesian cows during milking with and without a premilking stimulus, J. Dairy Sci. 53 (1970) 747-751.

[26] Murugaiyah M., Ramakrishnan A.R., Sheikh Omar A.R., Knight C.H., Wilde C.J., Lactation failure in crossbred Sahiwal Friesian cattle, J. Dairy Res. 68 (2001) 165-174.

[27] National Research Council, Nutrient requirements of dairy cattle, 6th rev. ed., Natl. Acad. Sci., Washington, DC, 1989.

[28] Negrão J.A., Marnet P.G., Kann G., Evolution of oxytocin, prolactin and cortisol release during first milkings of primiparous ewes, EAAP Publication 95 (1998) 73-78. 
[29] Negrão J.A., Marnet P.G., Kann G., Comparison of oxytocin, prolactin, and cortisol release during the first and second lactation, EAAP Publication 95 (1998) 79-84.

[30] Nostrand S.D., Galton D.M., Erb H.N., Bauman D.E., Effects of daily exogenous oxytocin on lactation milk yield and composition, J. Dairy Sci. 74 (1991) 2119-2127.

[31] Perez O., Jimenez de Perez N., Le Neindre P. Cochaud J., Production laitière de vaches Pie Noire traites ou allaitant 3 veaux, Ann. Zootech. 32 (1982) 475-482.

[32] Perez O., Jimenez de Perez N., Poindron P., Le Neindre P., Ravault J.P., Relations mère-jeune et réponse prolactinique à la stimulation mammaire chez la vache: Influences de la traite et de l'allaitement libre ou entravé, Reprod. Nutr. Dev. 25 (1985) 605-618.

[33] Plaut K., Bauman D.E., Agergaard N., Akers R.M., Effect of exogenous prolactin administration on lactational performance of dairy cows, Domest. Anim. Prod. 4 (1987) 279-285.

[34] Sandoval-Castro C.A., Anderson S., Leaver J.D. Influence of milking and restricted suckling regimes on milk production and calf growth in temperate and tropical environments, Anim. Sci. 69 (1999) 287-296.

[35] Sandoval-Castro C.A., Anderson S., Leaver J.D. Production responses of tropical crossbred cattle to supplementary feeding and to different milking and restricted suckling regimes, Livest. Prod. Sci. 66 (2000) 13-23.
[36] SAS/STAT 1990, User's Guide, Version 6 , fourth ed., Vol. 2, 1990.

[37] Schams D., Mayer H., Prokopp A., Worstorff $\mathrm{H}$., Oxytocin secretion during milking in dairy cows with regard to the variation and importance of a threshold level for milk removal, J. Endocrinol. 102 (1984) 337-343.

[38] Souza E.M., Milagres J.C., Regazzi A.J. Martinez M.L., Almeida e Silva M., Genetic and environmental effects on milk yield in Gir dairy herds, Rev. Soc. Bras. Zoot. 25 (1996) 889-901.

[39] Syrstad O., Heterosis in Bos taurus $\times$ Bos indicus crosses, Livest. Prod. Sci. 12 (1985) 299-307.

[40] Syrstad O., Dairy cattle cross-breeding in the tropics: performance of secondary cross-bred populations, Livest. Prod. Sci. 23 (1989) 97-106.

[41] Tancin V., Harcek L., Broucek J., Uhrincat M. Mihina S., Effect of suckling during early lactation and changeover to machine milking on plasma oxytocin and cortisol levels and milking characteristics in Holstein cows, J. Dairy Res. 62 (1995) 249-256.

[42] Tancin V., Kraetzl W-D., Schams D., Bruckmaier R.M., The effects of conditioning to suckling, milking and of calf presence on the release of oxytocin in dairy cows, Appl. Anim. Behav. Sci. 72 (2001) 235-246. 